\title{
Age Greater than 85 Years
}

National Cancer Institute

\section{Source}

National Cancer Institute. Age Greater than 85 Years. NCI Thesaurus. Code C138936.

An indication that an individual's age is or was greater than 85 years. 